\title{
睪丸腫瘍転移による下半身麻痺
}

\author{
国立横須賀病院泌尿器科（医長：古畑哲彦） \\ 古畑 哲彦 小川 勝明 山口 豊明 \\ 横浜市大泌尿器科教室（主任：穂坂正彦教授） \\ 菅原 敏 道 穂 坂 正彦 \\ 藤沢市民病院泌尿器科 \\ 広川信 \\ 横須賀共済病院泌尿器科 \\ 里 見 佳 昭 \\ 横浜日赤病院泌尿器科 \\ 石塚栄 -
}

\section{PARAPLEGIA BY METASTATIC TESTICULAR TUMOR}

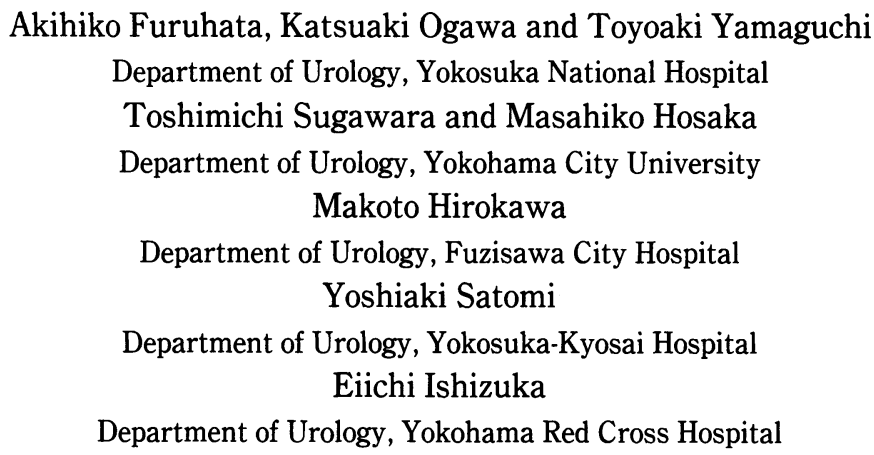

Six cases of paraplegia due to metastasis of a testicular tumor were reported. The paralysis was caused by vertebral epidural metastasis in 5 cases of these 6 and by a compression fracture of vertebra in the remaining 1 case. In the former 5 cases there were premonitory symptoms before the paralysis occurred. Myelography proved to be effective in diagnosing vertebral lesions. Therepeutic results in this small series of cases were briefly summarized as follows: neurologic response rate, $3 / 6$ or $50 \%$; complete response rate of tumor, $4 / 6$ or $67 \%$; 2 cases had "no evidence disease" of long duration.

Experiences with these cases tell that it is necessary for the physician to bear the possible occurrence of metastasis always in mind while making post-treatment follow-up observations of testicular tumor patients. Metastais, if occurs at all, should be detected as early as possible and whereupon chemotherapy, radiotherapy and surgery should be given in the most apropriate combination and time sequence so that relief of paralysis and eradication of metastatic tumor lesions might be accomplished.

要旨：殬丸腫瘍の転移により，下半身麻痷を生じた 6 例を報告した。 6 例中 5 例は脊椎硬膜外転移によ り, 他の 1 例は春椎骨圧迫骨折により下半身麻痷を生じた。脊椎硬膜外転移の 5 例はいずれも下半身麻 㾝となる以前に, 何らかの前駆症状が出現した。診断には myelography が有効であった. 我々の症例の 治療による neurologic responce rate は 3 / 6 で50\%, 腫瘍に対する治療効果は complete response rate が 4 / 6 で67\%であったが，長期間の no evidence disease 例は 2 例であった.

辠丸腫瘍の治療後の経過観察中, このような転移もあり得ることを念頭におき，見ていく必要がある. 
またこのよらな症例は早期に発見し, 化学療法, 放射線療法, 手術療法をらまく組合わせて, 麻痺の解 除と転移腫瘍の根治をめざさなければならない。

\section{対象および症例の概要}

我々は，横浜市大，国立横須賀病院および関連の施 設で経験する賥丸腫瘍症例を集計し，臨床的研究を 行っている.1978年から86年の 9 年間に経験し, 集計 した辠丸腫瘍症例は139例である。これらの症例中, 初
診時または経過中に転移を生じたものは45例で，この らち下半身麻痺を生じたものは 6 例であった。

Table 1 に 6 例の概要を示した。 年齢は27～57歳, 平均38.7歳であった。初診時 stage は I 2 例, IIB 3 例， IIIA 1 例で stage IIB， IIIA 例はすべて巨大転移

Table 1

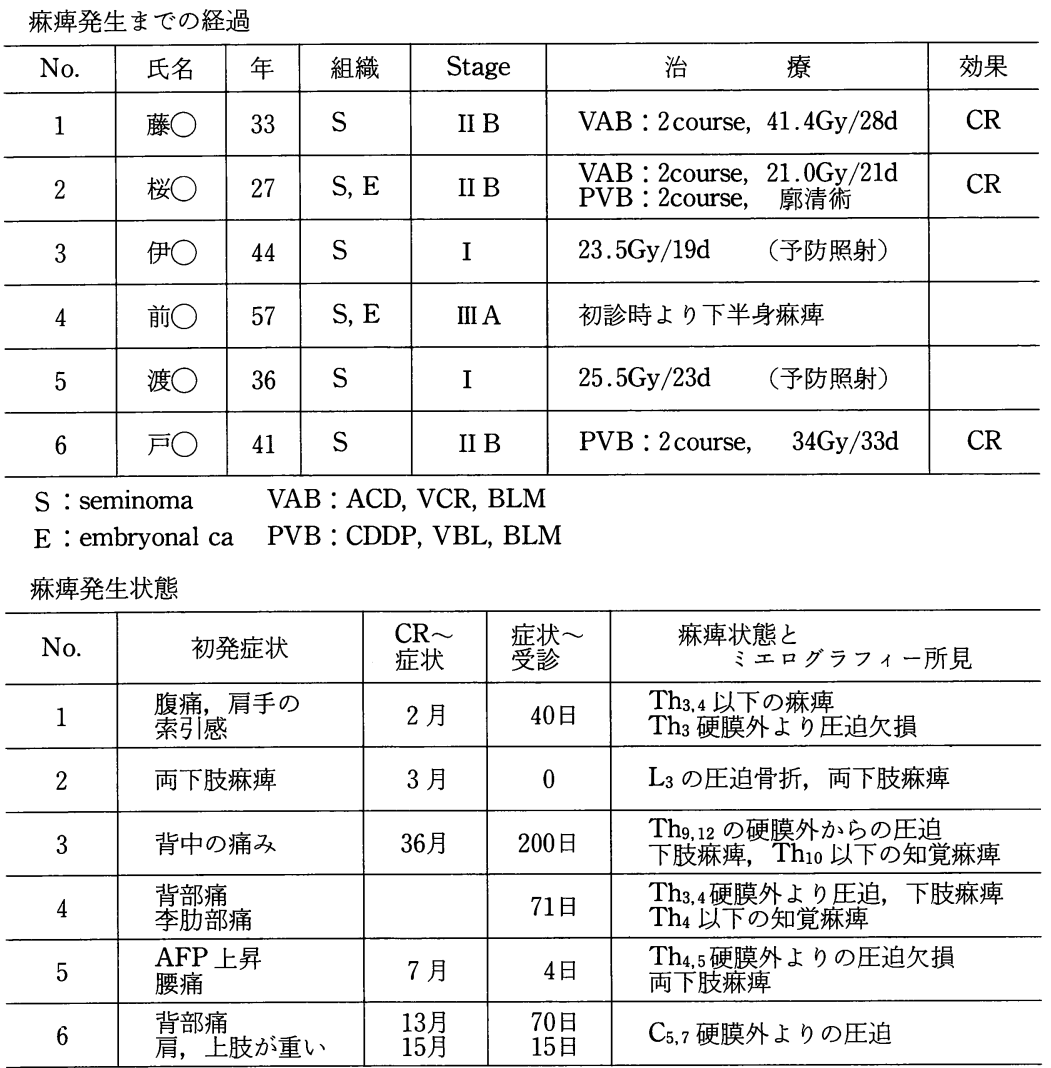

㾁痺に対する治療と予後

\begin{tabular}{|c|c|c|c|}
\hline No. & 治療 & 効 果 & 予後, 転移部位 \\
\hline 1 & $20 \mathrm{~Gy} / 13 \mathrm{~d}$ & 疼痛軽減 & $\begin{array}{l}7 \text { か月後死亡 } \\
\text { 肺, RPLN, 腎 }\end{array}$ \\
\hline 2 & 治療不能 & & $\begin{array}{l}2 \text { か月後死亡 } \\
\text { 肺, 肝, RPLN, 骨 }\end{array}$ \\
\hline 3 & $\begin{array}{l}\text { 切除術 } \rightarrow \text { PVB : } 3 \\
44 \mathrm{~Gy} / 30 \mathrm{~d}\end{array}$ & $\mathrm{CR} \rightarrow$ ハビリ & $\begin{array}{l}\text { 14か月後他病死 } \\
\text { 再発転移なし }\end{array}$ \\
\hline 4 & $\begin{array}{l}\text { 9Gy/7d, CDDP }: 3 \\
\mathrm{PVB}: 8\end{array}$ & $\mathrm{CR} \rightarrow$ リヒビリ & 8 年後 NED \\
\hline 5 & $\begin{array}{l}\text { PVB }: 4,42 \mathrm{~Gy} / 42 \mathrm{~d} \\
\text { PVB }: 2\end{array}$ & $\mathrm{CR} \rightarrow$ 㾁痺消失 & 4 年 8 か月後 NED \\
\hline 6 & $\begin{array}{l}\text { 切除, PVB : } 1 \\
\text { PEB }: 3,30 \mathrm{~Gy} / 24 \mathrm{~d}\end{array}$ & $\mathrm{CR} \rightarrow$ 㾁痺消失 & $\begin{array}{l}\text { 15か月後 RPLN 再発 } \\
\text { 化療 } \rightarrow \text { 切除 }\end{array}$ \\
\hline
\end{tabular}


腫瘍を有していた，初診時より下半身麻痺であった例 は症例 4 の 1 例の久で, 他はすべて初回治療後, 再発 にて下半身麻痷を生じている，初回治療としては， stage Iの 2 例には後腹膜リンパ節に対し，それぞれ 23.5Gy (gray), 25.5Gy の予防照射が行われた。 stage IIB の 3 例中, VAB (actinomycin-D, vincristine, bleomycin）療法を2 course 後, 放射線療法にて CR (complete response) となった例が 1 例, PVB (cisplatin, vinblastine, bleomycin) 療法を2course 後, 放射線療法にて CR となった例が 1 例あった。

前駆症状がなく，急に下半身麻痺を生じた例は，脊 椎転移により圧迫骨折を生じた症例 2 のみで, 他の 5 例は痛み，索引感などの何らかの刺激症状が先行して いた。そしてこれら 5 例はいずれも，脊椎硬膜外転移 による麻瘏例であった。初診時よりの麻痺のあった症 例 4 を除き, 初回治療にて CR となってから前駆症状 の出現までの期間は最短 60 日, 最長 3 年であった。 た前駆症状出現から麻痺発生までの期間は最短 4 日,

最長 6 カ月と20日であった。

麻痺の症状および主として myelography 所見によ る春髄圧迫レベルは, 症例 2 の圧迫骨折 $\mathrm{L}_{3}$ であった注 か, 胸椎の硬膜外転移によるものが 4 例, 頚椎の硬膜 外転移によるものが 1 例であった。胸髄の圧迫レベル は一定して打らず，多種多様であった。

これら症例の腫瘍に対する治療と予後としては，症 例 1 には腫瘍に対し20GY/13d (days)の照射を行った が， 7 カ月後死亡した。症例 2 は治療することもでき ず， 2 カ月後死亡した。症例 3 は手術, 化学療法, 放 射線療法にて CR が得られたが14力月後, 他病死した。 症例 4 は化学療法, 放射線療法により CR が得られ, リ 八ビリ中であるが，下肢麻痺は残存している。症例 5 は化学療法, 放射線療法により CR となり麻痺も消失 した. 症例 6 は化学療法, 手術, 放射線療法を行いCR が得られたが $15 カ$ 月後に後腹膜腔に再発し，化学療法 後切除した。

\section{症例}

症例 1。33歳, セミノーマ, stage IIB。

昭和50年頃上り右殬丸腫大に気付くも放置。初診： 昭和 53 年 5 月 25 日，右睪丸は小児頭大に腫大. 右季肋 部に超手拳大の硬い腫瘤が触れた. 血中 hCG, hCG- $\beta$, AFP は陰性. 血中 LDH $546 \mathrm{U} / \mathrm{ml} .5$ 月26日右高位除 辠術施行。術後, リンパ管 x-p などの諸検查により後 腹膜リンパ節の巨大転移腫瘍が確認された。

6 月12日よりVAB 療法を2course 施行。腫瘍はほ
とんど縮小せず， NC (no-change) 〜 PD (progressive disease)であった。9月 4 日より腹部腫瘍に対し，41.4 $\mathrm{Gy} / 23 \mathrm{f}$ (fraction)/28d の照射で腫瘍は消失.さらに後 腹膜からそけい部リンパ節に対しても予防照射を行っ た。

昭和54年 1 月右肩から手にかけて索引感と軽い痛み が発生. 2 月 8 日には右手のしびれ，胸痛を訴克た。 25 日，下半身麻舫および尿閉となり再入院した。 Myelography (Fig. 1) その他の検查により $\mathrm{Th}_{2} \sim \mathrm{Th}_{9}$ の春髄圧迫と判明. 同部に $19.8 \mathrm{~Gy} / 11 \mathrm{f} / 13 \mathrm{~d}$ の照射を 行ったが麻痺は解除されなかった。本例はその後, 間 もなく肺転移を生じて死亡した。剖検にて肺, 腹膜, 縦隔に転移が認められた。 $\mathrm{Th}_{2} \sim \mathrm{Th}_{9}$ の硬膜外には血 腫があるのみで腫瘍は消失していた。

症例 2.27歳, 七ミノーマ十胎生癌, stage IIB. 昭和52年末左辠丸腫大. 53 年 10 月除辠術施行(他医).

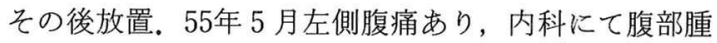
瘤発見。さらに睪丸腫瘍の転移診断にて泌尿器科転科。 CT, IVP, リンパ管 $\mathrm{x}-\mathrm{p}$ にて後腹膜リンパ節巨大転移 腫瘍あり. Stage IIB 診断。血中 AFP $3,100 \mathrm{ng} / \mathrm{ml}$, hCG 陰性. VAB 療法を2course 行うも腫瘍は縮小せ ず NC と判定. その後 PVB 療法を行い腫瘍は縮小し PR (partial response) と判定. しかし, 肝機能障害

Fig. 1 症例 1 の melography.

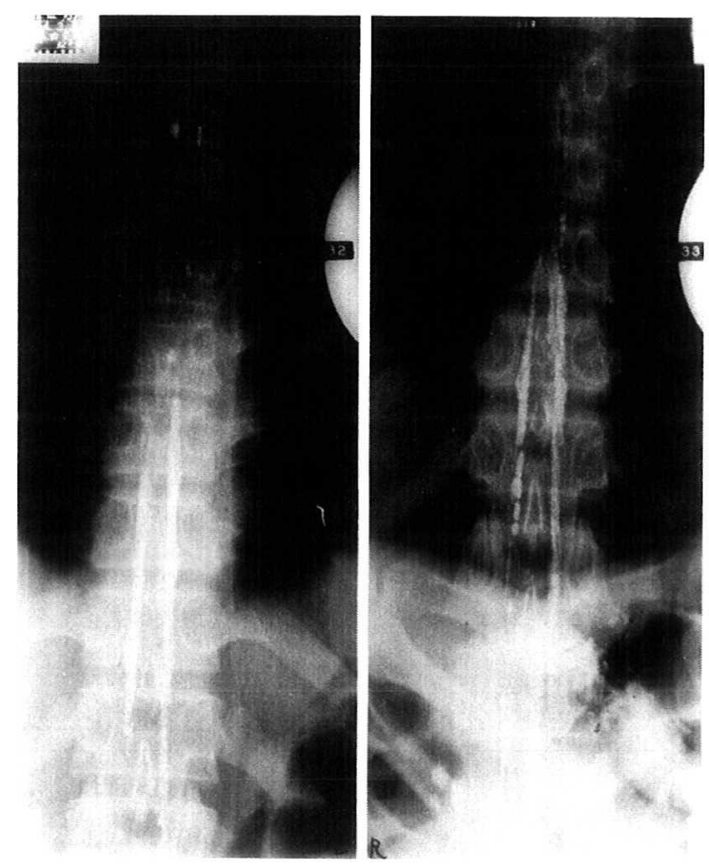


Fig. 2 症例 $2 . \mathrm{L}_{3}$ の圧迫骨折.

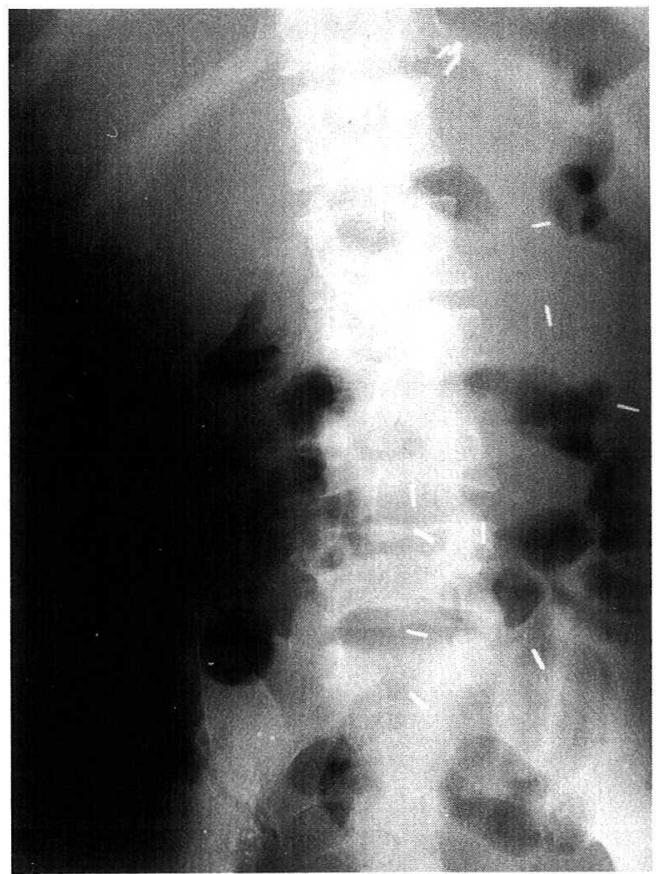

があったため化学療法は中止. 腫瘍に対し $21.0 \mathrm{~Gy} / 14$ f/21dの照射を行う。56年 5 月 13 日後腹膜リンパ節郭 清術施行. 腫瘍は $10 \times 5.5 \times 3.5 \mathrm{~cm}$. 摘出組織は胎生癌. 56 年 7 月 2 日肺転移出現。さらに本例は 8 月 31 日, $\mathrm{L}_{3}$ 脊椎骨圧迫骨折による下半身麻㽻発生 (Fig. 2). その 後治療のすべもなく，10月28日死亡した。剖検にて癌 性腹膜炎, 肺, 肝転移, 後腹膜リンパ節転移再発。ま た $\mathrm{L}_{3,4,5}$ 椎骨転移あり， $\mathrm{L}_{3}$ 椎骨虫圧迫骨折していた。

症例 3.44歳, 七ミノーマ, stage I.

昭和 53 年 12 月右睪丸腫大発見。 54 年 3 月 6 日, 右高 位除睪術施行. LDH $603 \mathrm{U} / \mathrm{ml}$. 血中 hCG, AFP 陰性. IVP, リンパ管 $\mathrm{x}-\mathrm{p}$ にて Stage I と判定. 後腹膜リンパ 節に対し $23.5 \mathrm{~Gy} / 47 \mathrm{f} / 19 \mathrm{~d}$ の予防照射を施行.

昭和 57 年 3 月より背部痛あり, 整形外科で治療して いた。同年10月，腰，下肢痛あり。その後歩行不能と なった。整形外科にて行った myelography にて $\mathrm{Th}_{10}$

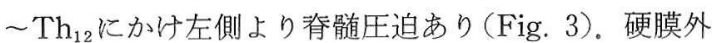
腫瘍診断のもとに57年12月12日硬膜外腫瘍切除が行わ れ, 下半身麻㽻は消失した。 その後, 泌尿器科に移り PVB 療法を合計3course 行った。

58年11月23日, 再び下半身麻痺となり $44 \mathrm{~Gy} / 22 \mathrm{f} / 30 \mathrm{~d}$ の照射を行った。しかし 12 月 25 日, リハビリ中急に心 筋梗塞を起し死亡した。
Fig. 3 症例 3 の myelography.

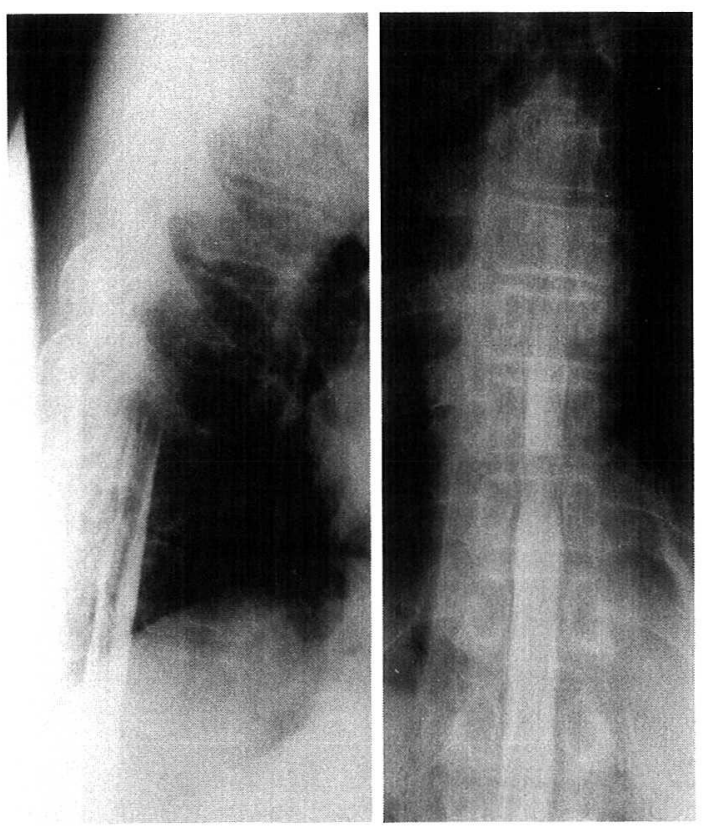

症例 4 .57歳, セミノーマ十胎生癌, stage IIIA.

8〜10年前より右そけい部鋅丸腫瘍に気付いていた が, 放置, 次第に腫大。昭和 54 年 6 月下半身麻痺とな り来院した。そけい部〜下腹部にかけ小児頭大の腫瘤 あり。睪丸腫瘍の診断のもとに 7 月 31 日高位除睪術を 施行。胸部 $\mathrm{x}-\mathrm{p}$, リンパ管 $\mathrm{x}-\mathrm{p}$ にて縦隔洞転移あり。ま た, 硬膜外腔造影 (Fig. 4)にて硬膜外腫瘍が認められ, myelography にて Th T $_{3}$ にかけ脊髄圧迫像があった。 緊急に縦隔洞へ $9.1 \mathrm{~Gy} / 7 \mathrm{f} / 7 \mathrm{~d}$ の照射を行ったが麻痺は 回復せず，化学療法に変更した。7月25日より週 1 回 の CDDP の治療により, 歩行は可能となった。その後 PVB 療法を2course 追加し, 除睪術後の 5 年 6 力月の 現在, 再発転移はみられない。

症例 6.41歳, 七ミノーマ, stage IIB.

昭和 57 年 10 月より左睪丸腫大あったが放置。初診： 昭和58年10月11日。術前 hCG $3,407 \mathrm{miu} / \mathrm{ml}, \mathrm{hCG}-\beta$ $11.9 \mathrm{ng} / \mathrm{ml}, \mathrm{LBH} 686 \mathrm{U} / \mathrm{ml}, \operatorname{AFP}(-)$. 10月14日左 高除睪術施行。CT, IVP, リンパ管 $\mathrm{x}-\mathrm{p}$ にて後腹膜に 巨大転移腫瘍あり, stage IIB と判定。11月 8 日より PVB療法を2course 施行。CT にて腫瘍は消失し CR と判定. その後, 後腹膜リンパ節に対し $36.0 \mathrm{~Gy} / 72 \mathrm{f} / 34$ d, 縦隔洞に25.0Gy/17f/21dの照射を行った。 昭和 60 年 3 月頃より背部痛あり。 5 月初旬には右肩 〜上腕にか惊鈍痛も生じた。同下旬には胸部痛も発生 
Fig. 4 症例 4 の硬膜外腔造影.

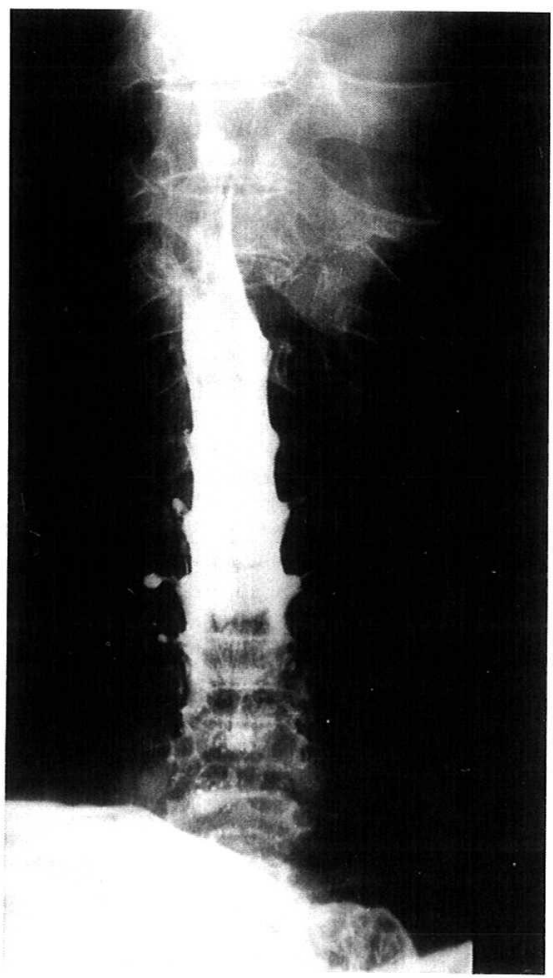

したため 5 月 27 日当科再診後入院した。 6 月 1 日硬膜 外造影にて $\mathrm{C}_{5 \sim 6}$ 部位の転移が考光られた。 6 月 3 日よ り下半身麻痺と排尿困難が発生. 同日の myelography にて $\mathrm{C}_{5 \sim 7}$ にけ硬膜外転移により脊䯣圧迫変位が認め られた。ただちにPVB療法 2 日間投与したが疼痛と 麻瘏が増強したため, 60 年 6 月 6 日 $\mathrm{C}_{4} \sim \mathrm{C}_{7}$ の laminectomy 施行. これにより疼痛は消失し麻瘒もと れた。その後 PVB療法を1course, PEB (CDDP, etoposide, bleomycin) 療法を3course 行い, $\mathrm{C}_{3} \sim \mathrm{Th}_{8}$ にかけ30.4Gy/21f/24d の照射を行った。その後再び hCG の上昇と CT 飞て後腹膜リシパ節に腫瘍の再発 あり, IAE (ifosphmide, adreamycin, etoposide) 療 法を2course 行った。さらに, 61 年 8 月 19 日後腹膜リン 節転移腫瘍摘出と廓清を行った。腫瘍は $6 \times 2.5 \mathrm{~cm}$ で, 病理組織診断はセミノーマであった。昭和62年に 入り, 大腿骨, 肺の転移が生じ現在も加療中である。

\section{考察}

\section{1. 発生頻度㧍よび転移経路}

泌尿性器系の腫瘍原発で, 脊椎硬膜外転移による下 半身麻㽻は, 何といっても前立腺癌によるものが多い.

Liskow ら $(1986)^{1)}$ の泌尿性器原発脊椎硬膜外転移
Fig. 5 症例 5 の myelography.

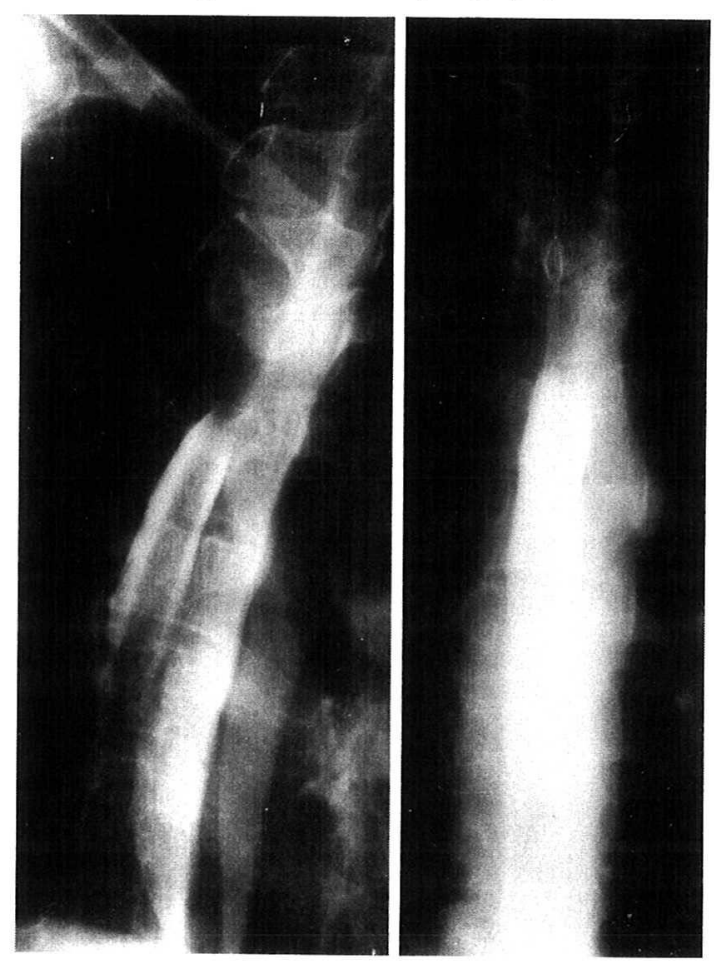

Fig. 6 症例 6 の myelography.

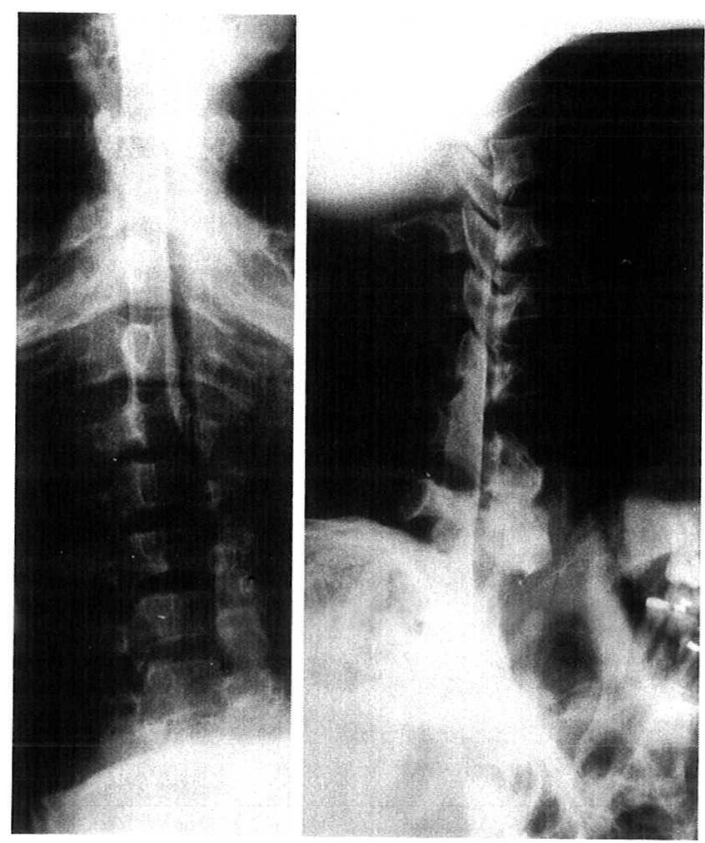


による下半身麻痺集計報告でも，21例中16例が前立腺 癌によるものである。睪丸腫瘍転移による下半身麻痺 の報告は極く少ない, 我々の調べ得た範囲でも, White

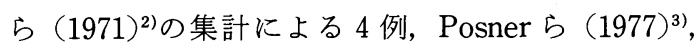
Nother $ら(1982)^{4)}$, Deb \& Sengupta $(1983)^{5}$, Obbens ら $(1984)^{6)}$ の各 1 例にすぎない。ただし Gilbert ら $(1978)^{7)}$ の報告中, 胎生癌という報告が 5 例あり，この 中の何例かは殬丸腫瘍である可能性がある。 また前述 の Liskow ら ${ }^{1)} 21$ 例の報告には辠丸原発は 1 例もな い.

詳細な症例の記載のある Posner ら)の例は原発は セミノーマで, $T h_{11}$ レベルの硬膜外転移のため下肢麻 舫之直腸膀脱障害を生じている。放射線療法後, CDDP を中心とした化学療法にて一時は通常生活可能となっ たが，その後再発あり，再び下半身麻㽻のままになっ たと報告している。

我々は過去 6 年間に 6 例の睪丸腫瘍転移による下半 身麻㽻例を経験している。この 6 例中 5 例は, 硬膜外 転移腫县の脊髄圧迫によるものであった。我々は睪丸 腫瘍につき昭和38年より関連病院の症例を集計し, 臨 床的研究を行っているが, 昭和51年以前の症例ではこ のようにはっきりとした硬膜外転移による症例は経験 していない。昭和53年頃より辠丸腫瘍の化学療法が有 効となり，転移ある症例も治癒し得るようになってき
た。硬膜外転移の出現は, 原因は不明だが化学療法の 発展之関係あるか子知れない。すなわち, 化学療法発 達以前の症例では, 他藏器に転移が生ずると短期間に 死亡してしまって, 下半身麻㽻のまま長期生存する例 は少なかったと思われる。

Liskow ら ${ }^{1)}$, Rodrigueg ら (1980) $)^{8}$ は硬膜外腔への 転移経路として，1）肺, 乳癌などの椎骨転移からの侵 展,2）悪性リンパ腫などによる近くのリンパ節からの 浸潤，3）Batsons plexus または radicular arterysよ りの血行性転移を挙げている，幸丸腫瘍の場合は 2 ), 3)のいずれも考えられる.

Fig. 7 は椎骨, 春髄, 硬膜の横断面と䊓断面図を示 す9). 脊椎硬膜外には内外椎骨静脈叢があり, これは上 下, 左右互いに交通を有するとともに, 腰動静脈々通 ずる．前立腺癌の転移経路として，この内外静脈叢を 通じて硬膜外腔に転移を生じ，さらに椎骨に進展する 経路が考えられている。この経路は前立腺癌ばかりで なく, 他の泌尿器科癌でもあり得る.

我々の症例では, 初診時から麻疸を生じた例は少な く，6 例中 1 例にすぎない。他の 5 例はすべて経過観 察中か，他の転移腫瘍の治療後に発生している。しか も, 6 例中 3 例は後腹膜の転移腫瘍の治療後, 硬膜外 腔に再発し麻瘒を生じている。このような症例の経験 により辠丸腫湯の転移経路として, 直接静脈叢に転移

Fig. 7 腰椎の血行（吉沢英造9)より引用）
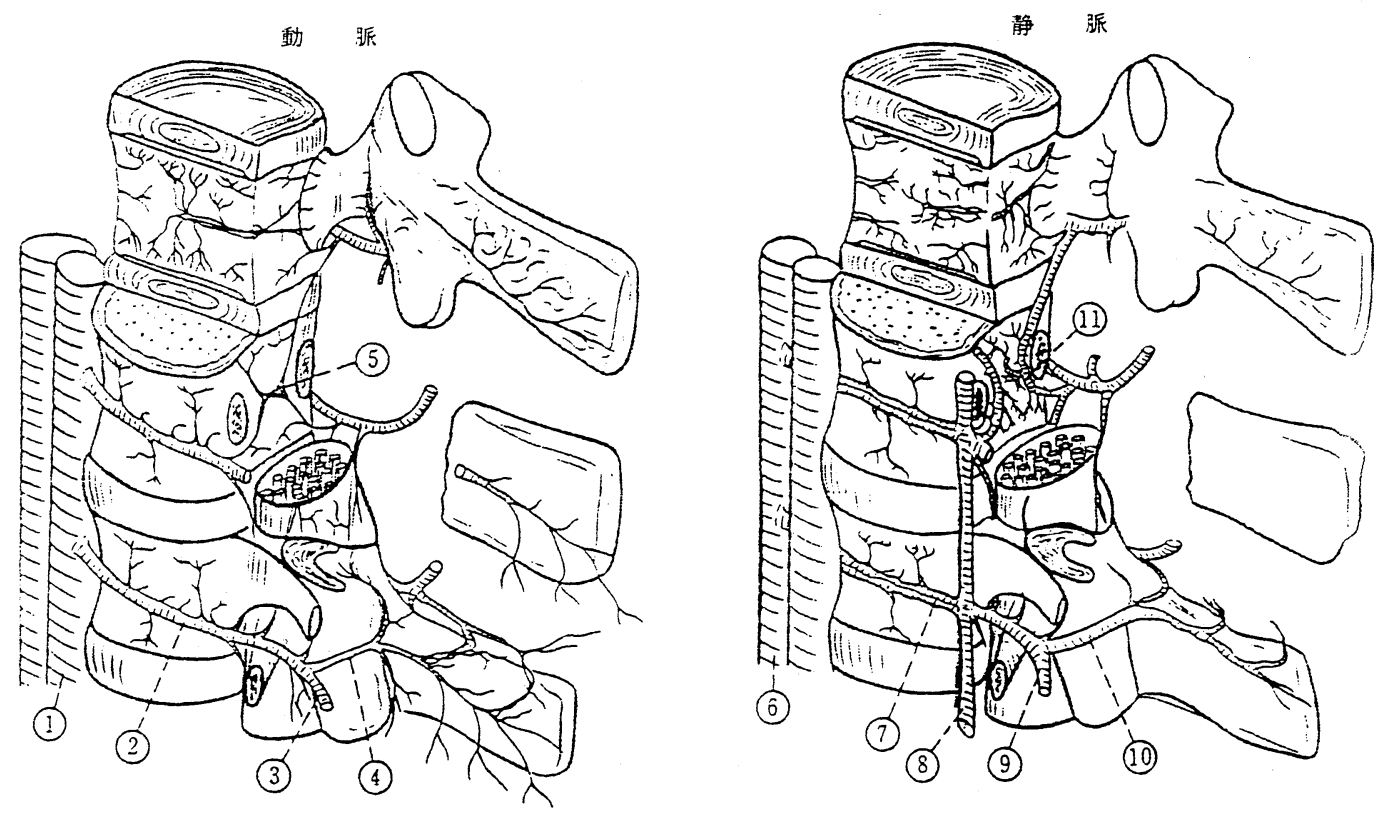
するというょりむしろ, 後腹膜リンパ節転から腰静脈 を通じて, 硬膜外腔に転移を生ずる経路が考兄られる。

硬膜外腔に転移腫瘍が発生する場合，その高さは決 まっていない. Liskow ら ${ }^{11}$ は䅡〜胸椎7\%, 胸椎 $73 \%$ と 報告している. 我々の例でも胸椎が 4 例, 頝椎が 1 例 であったが, 椎骨静脈叢は上下の交通があることより， 腫瘍がどの高さに住及付いても不思議ではない.

2. 症状, 診断, 検査

本症は何といっても早期に診断し, 神経障害が固定 化しないうちに圧迫を解除すべきである。このために は辠丸腫瘍患者の経過観察中は，このような転移もあ り得ることを常に念頭に打くべきである.

本症の前駆症状としてはいろいろの報告がみられる が, やはり痛及が最も多く11388), これが早期発見の手が かりとなる。この他に脱力, 感覚麻疸も生ずる18) とい 万. 我々の症例でも, 圧迫骨折を生じた症例 2 を除き, 6 例中 5 例が下半身麻瘏となる前に, 何らかの前駆症 状が出現している。前駆症状の期間は症例 5 のように 極く短い例もあったが, 他は25〜200日とかなりの間隔 がある. 我々は症例 $1 \sim 4$ の経験より, 症例 5,6 で は下半身麻㽻は生じたが, 前駆症状より比較的早期に 検查を行い, 治療により麻痺は消失し歩行可能となっ ている.

上記のごとく，前駆症状を早期に把握して確定診断 と部位診断を行らが, これには各種理学的検査の他, myelography と CT が有効である ${ }^{1) 8}$. 我々の例では症 例 2 は単純 x-p にて骨破壊像があり診断も容易であっ たが, 他の症例 1，3〜6は myelography が確定診断 の根拠となっている. myelography の所見としては, 硬膜外腫瘍による圧迫，狭窄が主体である。

\section{3. 治療と予後}

治療に際しては，二つのことを念頭に行わなければ ならない.すなわち，一般の悪性腫瘍と同様に神経麻 盘を解除するために，早期に手術的処置を行い，圧迫 を取ることも必要である。一方, 辠丸腫瘍に限っては, 転移腫瘍でも根治を目標としなければならない。そし て，この両者はある意味では相反することにもなる。

硬膜外転移による下半身麻瘒例に対しては, 一般に は緊急手術による圧迫解除のための laminectomy が 適応とされている(12)810) 12). これにより麻痺を防ぐと 同時に, でさる限り腫瘍の切除も試みる。手術が有効 の場合，麻瘏は劇的に回復するが，間に合わない例も 多い. また，一般には根治的切除は不可能である ${ }^{133) 8}$. したがって, 術後の放射線療法, 化学療法が重要とな
る。一般の悪性腫瘍の手術または，放射線潦法による 全体の治療成績は比較的悪く, neurologic response rate は Gilbert ら 一方, 転移が悪性リンパ腫の場合は手術せず, 緊急に 放射線療法を行う場合が多く，治療効果も 70 75\% 之比較的良い。

兽丸腫瘍の場合は化学療法や放射線療法が有効のた め, より良い response rate が期待され, 他臟器への転 移と同様に根治性をめざさなければならない。した がって, 他の悪性腫瘍とは異なった輧丸腫瘍独自の治 療方法が考号らる。

転移性粹丸腫瘍の治療は, 一般には化学療法を先行 し，併用療法を2３course 行い，CR ならば経過観察， PR の場合は残存腫瘍摘出を行 5 . 硬膜外転移の場合 は神経麻疸との関係で, 選択がむずかしい場合が多い が，できる限りこの原則に沿うよう治療方針を立て， 完治をめざさなければならない。このためには神経麻 舫の状態, 進行状況拉よび化学療法の反応を正確に把 握し治療することが大切である，麻疸が非可逆的にな らないよう，いつでも手術ができるよう準備し，時期 を逸しないようにするとともに，麻痷が可逆性である ならば化学療法を優先し, 腫瘍縮小に努めることも大 切である。

我々の例では, 症例 3,4 は放射線療法と化学療法 により CR となったが, 症例 3 は他疾患にて死亡, 症例 4 は麻瘒が残存している. 症例 5,6 は化学療法, 手 術療法, 放射線療法をらまく組合わせ, 麻瘏の残存も なく CR となった。

一般にこのような症例の予後は悪く, 我々の例でも 6 例中 3 例がすでに死亡している. 前述のごとく, 全 身性転移の一型であることからも予後が覀いといえる 一方, 麻痷の解除が重要なため治療効果も上がりづら い.

以上, 辠丸腫瘍の硬膜外転移について述べてきたが, いずれにしても報告例も少なく, 今後さらに症例の集 計と分析が必要である. 特に化学療法の有効な時代に 入り, 治療しやすい部位は CR となっても, 硬膜外転移 のような治療しづらい腫瘍が残ってしまうことによ り, 今後症例が増加するものと考学られる。

\section{結語}

辠丸腫瘍の転移により, 下半身麻瘴を生じた 6 例を 集計報告し，併せて文献的考察を行った。

1） 6 例中 5 例は脊椎硬膜外転移により，1例は脊椎 骨圧迫骨折により下半身麻㽻を生じた. 
2) 殬丸腫瘍治療後経過観察中, このよらな転移も あり得ることを念頭に，早期発見早期治療が必要であ る.

3）治療は化学療法, 放射線療法, 化学療法をうまく 組合わせ, 麻舫の解除と根治をめざすべきである.

本論文の要旨は第24回日本癌治療学会総会 (於松江) にて 報告した。

\section{文献}

1) Liskow, A., Chang, C.H., Desanctis, P., Benson, M., Fetell, M. and Housepian, A.E.: Epidural cord compression in association with genitouriary neoplasms. Cancer, 58, 949-954, 1986.

2) White, W.A., Patterson, R.H. and Bergland, R. M. : Role of surgery in the treatment of spinal cord compression by metastatic neoplasms. Cancer, 27, 558-561, 1972.

3) Posner, J.B., Howison, J. Ajd Cvikovis, E.: Disappearing spinal cord compression oncologic effect of glucocorticoid (and chemotherapeutic agents) on epidural metastates. Annals of Neurology, 2, 409-413, 1977.

4) Nather, A. and Bosk, K.: The results of decompression from metastatic extradural tumors. Clin,. Orthop. and Related Res., 169, 103-108, 1982.

5) Deb, H.K. and Sengupta, P.: Spinal cord compression by metastatic testicular enbryonal carcinoma. J. Indan M.A., 81, 168-170, 1983.
6) Obbens, E., Kim, J.H., T halar, H., Deck, M. and Posner, J.: Metronidazole as a radiation enhancer in the treatment of metastatic epidural spinal cord compression. J. of Neuro-Oncology, 2, 99-104, 1984.

7) Gilbert, R.W., Kim, J.H. and Posner, J.B.: Epidural spinal cord compression from metastatic tumor: Diagnosis and treatment. Annals of Neurology, 3, 40-51, 1987.

8) Rodriguzed, M. and Dinapoli, R.T.: Spinal cord compression with special reference to metastatic epidural tumors. Mayo Clin. Proc., 55, 442-448, 1980.

9) 吉沢英造: 腰部春椎管狭窄症, 血行支配. 整形外科 Mook, 41, 24-31, 1985.

10) Young, R.F., Post, E.M. and King, G.A.: Treatment of spinal epidural metastates. Randmized prospective compression of lamincectomy and radiotherapy. J. Neurosurgery, 53, 741-748, 1980.

11) Dunn, R.C., Kelly, W.A., Whons, R.N.W. and Howe, J.F.: Spinal epidural neoplasia. A 15year review of the results of surgical therapy. J. Neurosurgery, 52, 47-51, 1980.

12) Calkins, A.R., Olson, M.A. and Ellis, J.H.: Impact of myelography on the $r$ adiotherapeutic management of malignant spinal cord compression. Neurosurgery, 19, 614-616, 1986.

(1988年 6 月 10 日受理) 